\title{
Synthesis, Characterisation and Antimicrobial Activity of Dimeric and Monomeric Copper(II)-Schiff base Complexes
}

\author{
Ane F. da S. Santos ${ }^{1}$, Leandro L. de Oliveira ${ }^{2}$, José R. da S. Maia ${ }^{1 *}$ \\ 1 Departamento de Química, Universidade Federal de Viçosa, Campus Universitário, Viçosa, Minas Gerais, \\ Brasil, 36570-900 \\ 2 Departamento de Biologia Geral, Universidade Federal de Viçosa, Campus Universitário, Minas Gerais, \\ Brasil, 36570-900
}

\begin{abstract}
Novel copper(II)-Schiff base derivatives were prepared in 1:1 and 1:2 (M:L) molar ratio reaction in ethanol. These compounds were characterized by infrared, UV-VIS, conductivity measurements, elemental analysis and melting point (decomposition). Dimers of general formula $\left[\mathrm{Cu}(\mathrm{L})\left(\mathrm{H}_{2} \mathrm{O}\right)\right]_{2} \cdot \mathrm{H}_{2} \mathrm{O}\{\mathrm{L}=3$-hmp (1) or 4-hmp (3)\} and [Cu(hmyp) $\left.\mathrm{Cl}_{2}\right]_{2}$ (4) were prepared and a monomer of $\left[\mathrm{Cu}(3-\mathrm{hmp})_{2}\left(\mathrm{H}_{2} \mathrm{O}\right) \mathrm{Cl}_{2}\right] \cdot \mathrm{H}_{2} \mathrm{O}$ (2). These chemicals are non-electrolytes and have the chloride ions bonded to the metal in terminal, bridging and trans position to the metal, performing geometric patterns of a square planar and square pyramidal arrangements. The UV-VIS of these complexes showed electronic transitions of molar extinction coefficients $(\varepsilon)$ between $10^{2}$ and $10^{3} \mathrm{~L} \mathrm{~mol}^{-1} \mathrm{~cm}^{-1}$ related to Metal-to-Ligand Charge Transfer (MLCT) bands and d-d transitions. The bioassay of the ligands and the metal derivatives were screened against Gram-positive (Staphylococcus aureus and Bacillus subtillis), and Gram-negative (Escherichia coli and Salmonella typhimurium) microorganisms. Complex-4 and the ligands hmyp and 4-hmp showed minimum inhibition concentration (MIC) in the range of 190 to $1020 \mu \mathrm{M}\left(40\right.$ to $350 \mu \mathrm{g} \mathrm{mL} \mathrm{L}^{-1}$ ) against these microorganisms but complex-1, 2 and $\mathbf{3}$ were not active.
\end{abstract}

Keywords: antimicrobial activity, copper(II) complexes, Schiff base, bactericide, coordination compounds

\section{Introduction}

Schiff bases are compounds acknowledged as fungicide [1], bactericide [2], antiviral [3] as well as antitumor drugs [4]. Considerable results on biological activity of metal-Schiff base derivatives reveal the potential of these compounds to become commercial drugs in the treatment of human diseases. Transition metal Schiff base complexes are reported to give better antimicrobial results in comparison to free Schiff bases, supporting the coordination compounds as good candidates in the whole of therapeutic treatments [5]. Since the discovery of cisplatin, the amount of active compounds based on metals and transition metals have been rising. For instance, copper(II) derivatives of Schiff bases are recognized for the treatment of several illnesses, including cancer therapy $[6,7]$.

The development of novel and effective drugs with low cost and less side effects are desirable to replace the commercial medicines. It becomes a challenge to researchers in the field to achieve this goal because of the resistance of microorganisms to commercial drugs, imposing limits on the community treatment and therefore increasing security risk to public health.

To continue with our research program on the development of biological active transition metal coordination compounds, three novel Schiff bases (3-hmp, 4-hmp and hmyp) and four copper(II) derivatives have been prepared and characterized. These compounds were screened against Gram-negative and Grampositive microorganisms to evaluate their potential to become antimicrobial drugs.

\section{Materials and methods}

All chemicals purchased from Sigma-Aldrich, Vetec and FMaia companies were used without prior purification. Elemental analysis was obtained from a Perkin Elmer 200 CHNS Elemental Analyzer. A Conductivity Jenway Meter 4010 was used to gather information on the molar conductivity $(\Omega M)$ of the copper(II) complexes in methanol at the concentration of $10^{-3} \mathrm{~mol} \mathrm{~L}^{-1}$. The infrared spectra were obtained from a Perkin Elmer FT-IR 1000 using Nujol between CsI windows. The UV-VIS spectra were recorded in a spectrophotometer Varian Cary 50, using quartz cuvette in the range of 200 to $800 \mathrm{~nm}$. The minimum inhibitory concentration (MIC) was determined by broth microdilution method using a spectrophotometer Eliza $(600 \mathrm{~nm})$ and microplates BioRad model 3550-UV, USA. 


\subsection{Synthesis of Schiff Bases}

Three Schiff bases were prepared by reacting 3-, 4-aminophenol and 2-amino-2-methylpropan-1-ol with 2-hydroxybenzaldehyde. The structures of these Schiff bases are showed in Fig. 1.

\section{(E)-2-((3-hydroxyphenylimino)methyl)phenol (3-hmp)}

To a round-bottom flask of $100 \mathrm{~mL}, 1.00 \mathrm{~g}(9.16 \mathrm{mmol})$ of 3-aminophenol was dissolved in ethanol $(60 \mathrm{~mL})$. Then, $1.11 \mathrm{~g}(0.97 \mathrm{~mL}, 9.09 \mathrm{mmol})$ of 2-hydroxybenzaldehyde was added into the mixture which was allowed to reflux under stirring for $4 \mathrm{~h}$. Subsequently, half of the solvent was removed under reduced pressure and the flask reserved in a freezer. After cooling, an orange solid separated from the mixture, which was filtered off in air, washed with hexane and stored in desiccators.

Yield of $2.00 \mathrm{~g}(95 \%)$; $\mathrm{Mp}\left({ }^{\circ} \mathrm{C}\right): 123.5$ - 124.7; Elemental analysis required for $\mathrm{C}_{13} \mathrm{H}_{11} \mathrm{NO}_{2}: \mathrm{C}, 73.23 ; \mathrm{H}, 5.20$; N, 6.57; found: C, 74.40; H, 5.35; N, 6.73. IR (Nujol / CsI): $3320 \vee(\mathrm{OH}) ; 1616 \vee(\mathrm{C}=\mathrm{N}) ; 1591,1501 v(\mathrm{C}=\mathrm{C})$; $1288 v(\mathrm{C}-\mathrm{O}) ; 1163 v(\mathrm{C}-\mathrm{N}) ; 844,755 \delta(\mathrm{C}-\mathrm{H})$

\section{(E)-2-((4-hydroxyphenylimino)methyl)phenol (4-hmp)}

This compound was synthesized following the procedure described for 3-hmp, using $1.0 \mathrm{~g}(9.16 \mathrm{mmol})$ of 4aminophenol and $1.26 \mathrm{~g}(1.10 \mathrm{~mL}, 10.31 \mathrm{mmol})$ of 2-hydroxybenzaldehyde.

Colour: yellow. Yield of $1.89 \mathrm{~g}(84 \%)$; $\mathrm{Mp}\left({ }^{\circ} \mathrm{C}\right)$ : 128.6 - 131.4; Elemental analysis required for $\mathrm{C}_{13} \mathrm{H}_{11} \mathrm{NO}_{2}: \mathrm{C}_{\text {, }}$ 73.23; H, 5.20; N, 6.57; found: C, 73.73; H, 5.32; N, 6.64. IR (Nujol / CsI): 3266 v(OH); $1617 v(\mathrm{C}=\mathrm{N}) ; 1572$, $1508 v(\mathrm{C}=\mathrm{C}) ; 1259 v(\mathrm{C}-\mathrm{O}) ; 1187 v(\mathrm{C}-\mathrm{N}) ; 839,755 \delta(\mathrm{C}-\mathrm{H})$

(E)-2-((1-hydroxy-2-methylpropan-2-ylimino)methyl)phenol (hmyp)

To a round-bottom flask of $100 \mathrm{~mL}, 2.00 \mathrm{~g}(2.10 \mathrm{~mL}, 22.4 \mathrm{mmol})$ of 2-amino-2-methylpropan-1-ol was dissolved in hexane $(60 \mathrm{~mL})$. Then, $2.70 \mathrm{~g}(2.30 \mathrm{~mL}, 22.10 \mathrm{mmol})$ of 2-hydroxybenzaldehyde was added into the flask and the mixture allowed to reflux under stirring for $4 \mathrm{~h}$. The resulting yellow mixture was set aside in a freezer for $24 \mathrm{~h}$. After cooling, a green-yellowish material separated from the mixture, which was filtered off in air, washed with hexane and stored in desiccators.

Yield of $3.00 \mathrm{~g}(64 \%)$; $\mathrm{Mp}\left({ }^{\circ} \mathrm{C}\right): 60.9$ - 61.3; Elemental analysis required for $\mathrm{C}_{11} \mathrm{H}_{15} \mathrm{NO}_{2}: \mathrm{C}, 68.37 ; \mathrm{H}, 7.82 ; \mathrm{N}$, 7.25; found: C, 69.56; H, 7.44; N, 7.77. IR (Nujol / CsI): $3259 v(\mathrm{OH}) ; 1631 v(\mathrm{C}=\mathrm{N}) ; 1582,1502 v(\mathrm{C}=\mathrm{C}) ; 1281$ $v(\mathrm{C}-\mathrm{O}) ; 1154 v(\mathrm{C}-\mathrm{N}) ; 866,767 \delta(\mathrm{C}-\mathrm{H})$.<smiles>Oc1cccc(/N=C/c2ccccc2O)c1</smiles>

(E)-2-((3-hydroxyphenylimino)methyl)phenol (3-hmp)<smiles>Oc1ccc(/N=C/c2ccccc2O)cc1</smiles>

(E)-2-((4-hydroxyphenylimino)methyl)phenol (4-hmp)<smiles>CC(C)(CO)/N=C/c1ccccc1O</smiles>

(E)-2-((1-hydroxy-2-methylpropan-2-ylimino)methyl)phenol (hmyp)

Figure 1. Molecular structures of the Schiff bases.

\subsection{Synthesis of Copper(II)-Schiff base derivatives}

To a round-bottom flask of $100 \mathrm{~mL}$, containing $30 \mathrm{~mL}$ of ethanol and 1.0 or $2.0 \mathrm{mmol}$ of the appropriate ligand (3-hmp, 4-hmp, hmyp), $1.0 \mathrm{mmol}$ of copper(II) chloride dehydrate was added and the mixture allowed to reflux for $4 \mathrm{~h}$ under stirring at $70{ }^{\circ} \mathrm{C}$. Subsequently, the solvent was removed under reduced pressure leaving behind an oil to which chloroform $(30 \mathrm{~mL})$ was added and the mixture stirred again for 30 minutes. The solids were filtered off in air washed with hexane and diethyl ether, and stored in desiccators.

$\left[\mathrm{Cu}(3-h m p)\left(\mathrm{H}_{2} \mathrm{O}\right) \mathrm{Cl}\right]_{2} \cdot \mathrm{H}_{2} \mathrm{O}(\mathbf{1})$. Colour: dark brown. Yield of $0.480 \mathrm{~g}(88 \%) ; \mathrm{Mp}\left({ }^{\circ} \mathrm{C}\right): 251 \mathrm{~d}$. Elemental analysis required for $\mathrm{C}_{26} \mathrm{H}_{26} \mathrm{~N}_{2} \mathrm{O}_{7} \mathrm{Cu}_{2} \mathrm{Cl}_{2}$ : C, 46.16; H, 3.87; N, 4.14; found: C, 46.28; H, 3.08; N, 4.03. IR (Nujol / CsI $): 3410 v\left(\mathrm{H}_{2} \mathrm{O}\right) ; 3310 v(\mathrm{O}-\mathrm{H}) ; 1607 v(\mathrm{C}=\mathrm{N}) ; 551 v\left(\mathrm{Cu}-\mathrm{OH}_{2}\right) ; 536 v(\mathrm{Cu}-\mathrm{O}) ; 466 v(\mathrm{Cu}-\mathrm{N}) ; 303,292 v(\mathrm{Cu}-$ $\mathrm{Cl}) . \Omega \mathrm{M}\left(\mathrm{CH}_{3} \mathrm{OH}, \mathrm{ohm}^{-1} \mathrm{~mol}^{-1} \mathrm{~cm}^{2}\right): 0.05$. 
$\left[\mathrm{Cu}(3-h m p) 2\left(\mathrm{H}_{2} \mathrm{O}\right) \mathrm{Cl}_{2}\right] \cdot \mathrm{H}_{2} \mathrm{O}$ (2). Colour: dark brown. Yield of $0.526 \mathrm{~g}(93 \%) ; \mathrm{Mp}\left({ }^{\circ} \mathrm{C}\right): 276 \mathrm{~d}$. Elemental analysis required for $\mathrm{C}_{26} \mathrm{H}_{26} \mathrm{~N}_{2} \mathrm{O}_{6} \mathrm{CuCl}_{2}: \mathrm{C}, 52.31 ; \mathrm{H}, 4.39 ; \mathrm{N}, 4.69$; found: $\mathrm{C}, 53.21 ; \mathrm{H}, 3.77 ; \mathrm{N}, 4.57$. IR (Nujol / CsI): $3450 v\left(\mathrm{H}_{2} \mathrm{O}\right) ; 3164 v(\mathrm{O}-\mathrm{H}) ; 1609 v(\mathrm{C}=\mathrm{N}) ; 521 v\left(\mathrm{Cu}_{-} \mathrm{OH}_{2}\right) ; 484 v(\mathrm{Cu}-\mathrm{N}) ; 314 v(\mathrm{Cu}-\mathrm{Cl}) . \Omega \mathrm{M}\left(\mathrm{CH}_{3} \mathrm{OH}\right.$, $\left.\mathrm{ohm}^{-1} \mathrm{~mol}^{-1} \mathrm{~cm}^{2}\right): 0.04$.

$\left[\mathrm{Cu}(4-h m p)\left(\mathrm{H}_{2} \mathrm{O}\right) \mathrm{Cl}\right]_{2} \cdot \mathrm{H}_{2} \mathrm{O}(3)$. Colour: dark brown. Yield of $0.334 \mathrm{~g}(91 \%) ; \mathrm{Mp}\left({ }^{\circ} \mathrm{C}\right): 251 \mathrm{~d}$. Elemental analysis required for $\mathrm{C}_{26} \mathrm{H}_{26} \mathrm{~N}_{2} \mathrm{O}_{7} \mathrm{Cu}_{2} \mathrm{Cl}_{2}: \mathrm{C}, 46.16 ; \mathrm{H}, 3.87 ; \mathrm{N}, 4.14$; found: $\mathrm{C}, 45.50 ; \mathrm{H}, 3.51 ; \mathrm{N}, 5.02$; IR (Nujol / CsI): $3430 v\left(\mathrm{H}_{2} \mathrm{O}\right) ; 3168 v(\mathrm{O}-\mathrm{H}) ; 1645 v(\mathrm{C}=\mathrm{N}) ; 518 v\left(\mathrm{Cu}-\mathrm{OH}_{2}\right) ; 484 v(\mathrm{Cu}-\mathrm{O}) ; 456 v(\mathrm{Cu}-\mathrm{N}) ; 310,294$ $v(\mathrm{Cu}-\mathrm{Cl}) . \Omega \mathrm{M}\left(\mathrm{CH}_{3} \mathrm{OH}, \mathrm{ohm}^{-1} \mathrm{~mol}^{-1} \mathrm{~cm}^{2}\right): 0.04$.

$\left[\mathrm{Cu}(\text { hmyp }) \mathrm{Cl}_{2}\right]_{2}$ (4). Colour: green. Yield of $0.263 \mathrm{~g}(46 \%) ; \mathrm{Mp}\left({ }^{\circ} \mathrm{C}\right): 155 \mathrm{~d}$. Elemental analysis required for $\mathrm{C}_{22} \mathrm{H}_{26} \mathrm{~N}_{2} \mathrm{O}_{4} \mathrm{Cu}_{2} \mathrm{Cl}_{4}$ : C, 40.57; H, 4.02; N, 4.30; found: C, 40.66; H, 5.28; N, 4.34. IR (Nujol / CsI): $3531 v(\mathrm{O}-$ $\mathrm{H})(\operatorname{sharp}) ; 1632 v(\mathrm{C}=\mathrm{N}) ; 452 v(\mathrm{Cu}-\mathrm{N}) ; 336,309,297 v(\mathrm{Cu}-\mathrm{Cl}) . \Omega \mathrm{M}\left(\mathrm{CH}_{3} \mathrm{OH}, \mathrm{ohm}^{-1} \mathrm{~mol}^{-1} \mathrm{~cm}^{2}\right): 0.06$.

\subsection{Minimum Inhibitory Concentration (MIC)}

The minimum inhibitory concentration was determined by the broth microdilution assays using microplates of 96 wells [8]. The metal standard solution was prepared by dissolving $1.0 \mathrm{mg}$ of the substance test in a mixture of DMSO $(250 \mu \mathrm{L})$ and sterile water $(750 \mu \mathrm{L})$. The microorganisms were grown in $3.0 \mathrm{~mL}$ of Luria Bertani (LB) medium at $37^{\circ} \mathrm{C}$ under stirring until an optical density (OD) range of 0.08 to 0.10 being achieved which contains 1.0 to $2.0 \times 10^{8}$ colony-forming unit (CFU) / mL. From the LB medium of each bacteria, $100 \mu \mathrm{L}$ (5.0 $\times 10^{4} \mathrm{CFU}$ ) of that was added to $50 \mu \mathrm{L}$ of the substance test respectively. Afterwards, the mixture was poured into the wells on the microplates and incubated for $24 \mathrm{~h}$. The MIC was obtained by the use of a spectrometer ELISA at $600 \mathrm{~nm}$. The experiment was finished in duplicate, considering the standard deviation. DMSO was the negative control, and the positive control was Amoxicillin and Norfloxacin.

\section{Results and Discussion}

The reactions to prepare the copper(II) Schiff base complexes were carried out in 1:1 and 1:2 (M:L) molar ratio of reactants. Irrespective of the stoichiometry used, complex-2 is 1:2, and complex-1, $\mathbf{3}$ and $\mathbf{4}$ are $1: 1$ concluding products. The molar conductivity of these compounds $(\Omega \mathrm{M})$ in methanol showed that these complexes are non-electrolytes.

\subsection{Infrared spectroscopy}

Typical vibrational bands of the Schiff bases, 3-hmp, 4-hmp and hmyp, related to the stretching mode of the hydroxyl and the imine bond were in the region of 3280 and $1621 \mathrm{~cm}^{-1}$, respectively [9-11]. Upon coordination, the vibrational band of the imine bond shifted almost $10 \mathrm{~cm}^{-1}$ towards low frequency in complex-1 and $\mathbf{2}$ and $28 \mathrm{~cm}^{-1}$ towards high frequency in complex-3. The infrared stretching of the imine bond in complex-4 did not shift significantly in comparison to the ligand hmyp. Frequently, the infrared stretching mode of the imine bond from Schiff bases have a slight shift upon coordination within the range of 10 to $25 \mathrm{~cm}^{-1}$ [5, 12].

The difference in infrared shift of the imine bond upon coordination between complex-1 and $\mathbf{3}$ reinforce the formation of chelating bonds of the type $\mathrm{N}-\mathrm{Cu}-\mathrm{O}$ having bidentate oxygen-terminal or bidentate oxygen-bridging bonds. For these two coordination modes, the vibrational stretching of the imine moiety depends on the delocalization of electrons within the $\mathrm{N}-\mathrm{Cu}-\mathrm{O}$ chelate rings, affecting the infrared shift. For instance, an infrared stretching of the terminal imine bond from a chelate ring containing oxygen-bridging atoms is expected to shift towards high frequency upon coordination owing to the delocalization of electrons comprising the oxygen-bridging atoms and the two copper(II) ions.

The insignificant infrared shift of the imine bond in complex-4, on the other hand, is an indication that the nitrogen atom is in trans position to the $\mathrm{Cu}-\mathrm{Cl}$ bond. The proximate electronegativity between these two atoms will balance the electron density of the imine bond, reducing the effect on its the infrared shift [13]. Similarly, the small infrared shift of the imine bond in complex-2 also indicates that the nitrogen atoms are in trans positon to the metal centre as a result of a monodentate coordination mode.

The vibrational stretching of the hydroxyl groups were assigned in the region of $3214 \mathrm{~cm}^{-1}$ in the spectra of complex-1, $\mathbf{2}$ and $\mathbf{3}$ which corroborates with the formation of hydrogen bonding [12-14]. In complex4, a narrow weak to medium band at $3521 \mathrm{~cm}^{-1}$ is also related to hydrogen bonding within the crystal lattice of this compound. Cesium(I) derivatives of lactose, $\mathrm{d}$-arabinose and l-arabinose also showed hydrogen bonding at $3520 \mathrm{~cm}^{-1}$ confirmed by the X-ray structural determination [14].

At the low-frequency, novel bands in the region $530 \mathrm{~cm}^{-1}$ were assigned to the wagging vibrational band of coordinated water in complex-1, 2 and 3; complex-4 did not show bands correlated to this vibrational mode $[12,13,15,16]$. The $\mathrm{Cu}-\mathrm{O}$ bond, formed by the loss of hydrochloric acid in complex-1 and $\mathbf{3}$, and the $\mathbf{C u}-$ $\mathrm{N}$ bond of all these complexes showed vibrational stretching in the region of $510 \mathrm{~cm}^{-1}$ and $472 \mathrm{~cm}^{-1}$ respectively $[12,13,15,17]$. Complex-1 and $\mathbf{3}$ also showed two bands associated with the bridging stretching modes of $\mathrm{Cu}-$ $\mathrm{Cl}$ bonds, contrasting with one band for complex-2 and three ones for complex-4 [13, 18]. For the latter two 
compounds, these bands supports to the formation of trans, terminal and bridging chlorides as showed by the proposed structures in Fig. 2 [13]. However, the $\mathrm{Cu}-\mathrm{Cl}$ infrared bands of complex-1 and $\mathbf{3}$ are also consistent with chlorides at the terminal position of a dimeric structure in which the metals are at the centre of a square pyramidal geometry. Two possible arrangements are conceivable concerning the $\mathrm{N}-\mathrm{Cu}-\mathrm{O}$ bidentate coordination mode as showed in Fig. 2. Both structural arrangements corroborate with the infrared stretching of the $\mathrm{Cu}-\mathrm{O}$ bond in complex-1 and $\mathbf{3}$ because of the slight difference in force constant between the bidentate oxygenbridging and oxygen-terminal coordination modes of these chelate bonding type.

The literature provide with information on dimeric and monomeric square planar palladium(II) derivatives of $\mathrm{N}$-heterocyclic carbene amidate alkoxide having both $\mathrm{N}-\mathrm{Pd}-\mathrm{O}$ chelating stretching modes. The Xray structural analysis of these palladium compounds showed that the dimer has shortened metal oxygenbridging bond length in comparison to the oxygen-terminal bond in the monomer [19]. The structural determination of dimeric square pyramidal copper(II) compounds derivative of N-(salicylidene)-N'-(imidazol-2ylmethylene)-1,3-propanediamine) also showed elongated metal oxygen-bridging bond length in addition to shortened ones which are associated with the axial or equatorial positon of the oxygen atoms within the structure. The infrared stretching of the coordinated imine moiety of those copper(II)-N-(salicylidene)derivatives was assigned at $1628 \mathrm{~cm}^{-1}$ corroborating with the infrared shift of the imine moiety in complex-1 and 3 [20]. Consequently, it is reasonable to assume that both complex-1 and $\mathbf{3}$ have dimeric structures with oxygenterminal bonds and bridging chlorides or oxygen-bridging bonds and terminal chlorides as showed in Fig. 2. Complex-1 most likely has oxygen-terminal bonds and complex-3 oxygen-bridging bonds, which are in agreement with the infrared shift of the coordinated imine bond and the $\mathrm{Cu}-\mathrm{O}$ bond stretching from both compounds as well. The formation of dimeric and monomeric structures of complex-1, 2, 3 and $\mathbf{4}$ in solid state is most likely an outcome of the 1:1 and 1:2 (M:L) stoichiometry among the reactants.
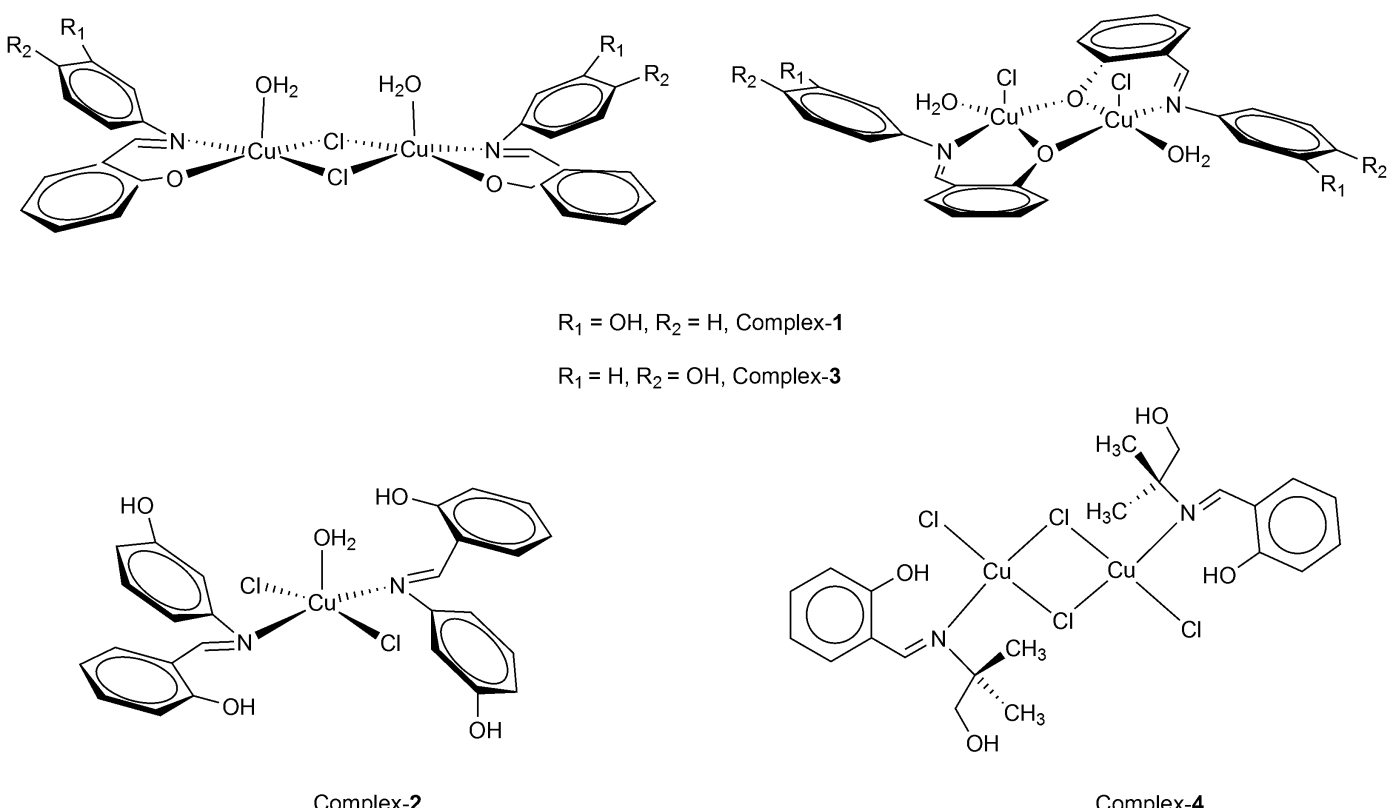

Figure 2. Proposed structures of the copper(II)-Schiff base complexes in solid state.

\subsection{Electronic spectra}

The electronic spectra of the Schiff bases, 3- and 4-hmp, in methanol and DMSO showed electronic transitions of the type $\mathrm{n} \rightarrow \pi$ and $\pi \rightarrow \pi^{*}$ in the range of 267 to $348 \mathrm{~nm}$. The ligand hmyp showed four bands in the range of 253 to $399 \mathrm{~nm}$ related to the former electronic transitions. These bands shifted upon coordination and have been observed in the spectra of the copper(II) derivatives within the range of wavelengths of the corresponding ligands as showed in Fig. 3.

The spectra of complex-1, 2 and $\mathbf{3}$ have revealed high intensity overlapped broad bands in the range of 260 to $500 \mathrm{~nm}$ in methanol and in DMSO. These electronic transitions fall within the visible region of the spectra as showed in Fig. 3, characteristic of Metal-to-ligand Charge Transfer (MLCT) bands. The spectrum of complex-4 also showed high intensity broad bands below $450 \mathrm{~nm}$ and a band of low intensity in both solvents in the region of $668 \mathrm{~nm}$. The extinction coefficients $(\varepsilon)$ of the estimated lowest energy band of complex-1, 2 and $\mathbf{3}$ were in the range of $10^{2}$ to $10^{3} \mathrm{~L} \mathrm{~mol}^{-1} \mathrm{~cm}^{-1}$ that corresponds to the transfer charge bands involving complexes having unsaturated ligands [21]. 

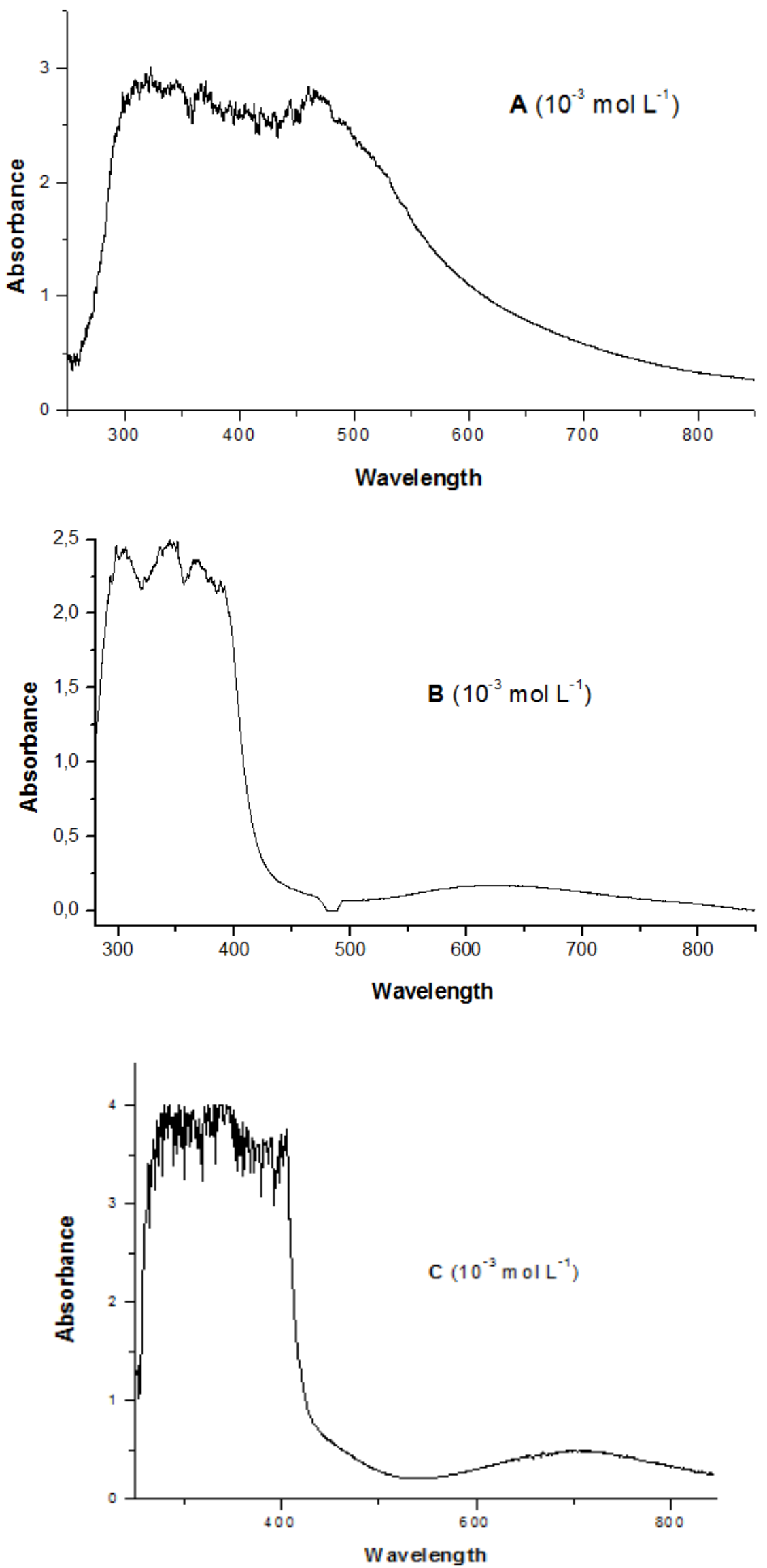


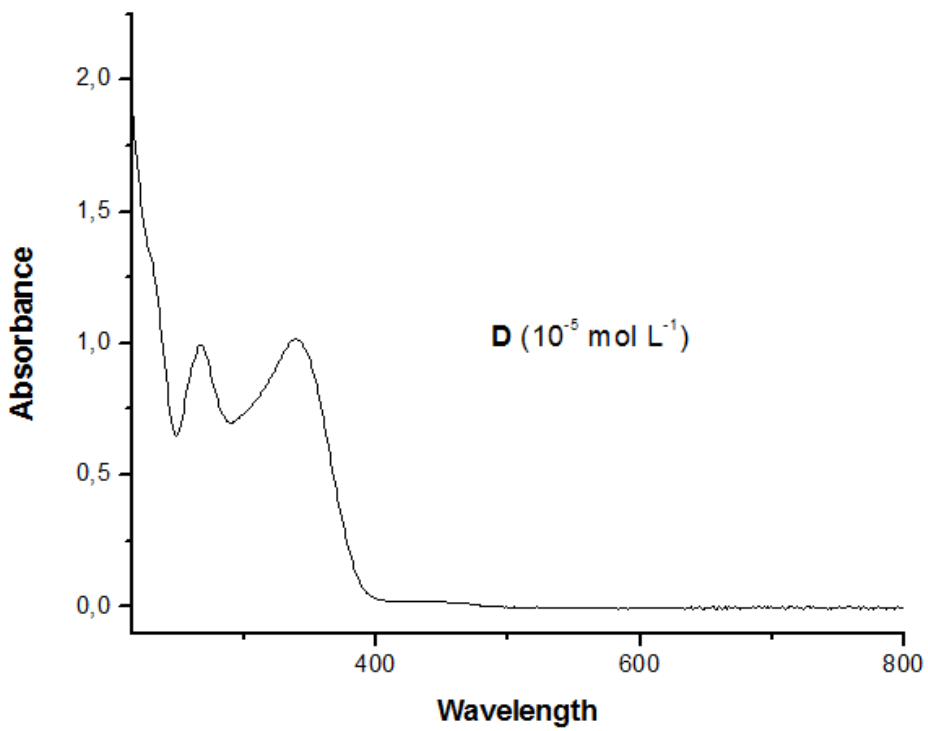

Figure 3. Spectra of complex-1 (A), complex-4 (B and C), and 3-hmp (D); A, B and D in methanol and $\mathrm{C}$ in DMSO. The spectra show MLCT, $d-d, \mathrm{n} \rightarrow \pi, \pi \rightarrow \pi^{*}$ transitions and saturation of the detector in $\mathrm{A}, \mathrm{B}$ and $\mathrm{C}$ below $500 \mathrm{~nm}$.

However, the lowest energy band in the UV-VIS region of complex-4 is most likely due to $d$ - $d$ electronic transitions at the metal centre. Square planar and square pyramidal copper(II) derivatives of Schiff bases, triazanone 2,6-diones and mixed ligands are reported to present $d-d$ transitions in the range of 600 to 770 $\mathrm{nm}$ and Ligand-to-Metal Charge Transfer (LMCT) bands in the range of 220 to $440 \mathrm{~nm}$. The extinction coefficient of these square planar and square pyramidal copper(II) compounds vary from 71 to $478 \mathrm{~L} \mathrm{~mol}^{-1} \mathrm{~cm}^{-1}$. The $\varepsilon$ value of complex $\mathbf{- 4}$ is within this range in both solvents, which reinforces a structural arrangement of a dimeric square planar geometry in solution [16, 17, 22-24].

The structural arrangements of these copper(II) complexes in solid state are probably preserved in methanol and in DMSO as revealed by the UV-VIS spectrum of complex-4 in both solvents. In addition, the non-electrolyte properties of them in methanol support the preservation of the original structures in solution, regardless of the coordinating property of DMSO [17]. The most significant UV-VIS bands of the Schiff bases and the corresponding complexes are showed in Table 1.

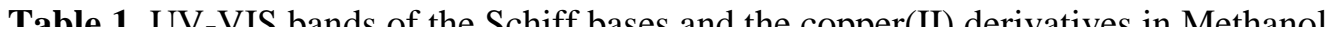

Compound Transitions Energy $\left(\mathrm{cm}^{-1}\right)$

$\{\mathrm{nm}, \varepsilon\}^{\ddagger}$

\begin{tabular}{|c|c|c|c|}
\hline 3-hmp & $\begin{array}{c}37,453 \\
(267 ; 15,434)\end{array}$ & $\begin{array}{c}29,498 \\
(339 ; 15,722)\end{array}$ & \\
\hline$\left[\mathrm{Cu}(3-h m p)\left(\mathrm{H}_{2} \mathrm{O}\right) \mathrm{Cl}\right]_{2} \cdot \mathrm{H}_{2} \mathrm{O}(\mathbf{1})$ & \multicolumn{2}{|c|}{ Overlapped bands below $500 \mathrm{~nm}$} & $\begin{array}{c}21,598 \\
(463 ; 2,309)^{\#}\end{array}$ \\
\hline$\left[\mathrm{Cu}(3-h m p)_{2}\left(\mathrm{H}_{2} \mathrm{O}\right) \mathrm{Cl}_{2}\right] \cdot \mathrm{H}_{2} \mathrm{O}(2)$ & \multicolumn{2}{|c|}{ Overlapped bands below $500 \mathrm{~nm}$} & $\begin{array}{c}21,276 \\
(470 ; 2,140)^{\#}\end{array}$ \\
\hline 4-hmp & $\begin{array}{l}37,037 \\
(270 ; 12,812)\end{array}$ & $\begin{array}{l}28,735 \\
(348 ; 23,808)\end{array}$ & \\
\hline$\left[\mathrm{Cu}(4-h m p)\left(\mathrm{H}_{2} \mathrm{O}\right) \mathrm{Cl}\right]_{2} \cdot \mathrm{H}_{2} \mathrm{O}(3)$ & \multicolumn{2}{|c|}{ Overlapped bands below $500 \mathrm{~nm}$} & $\begin{array}{c}15,748 \\
(635 ; 2,000)^{\#}\end{array}$ \\
\hline hmyp & $\begin{array}{c}39,525 \\
(253 ; 3,583)\end{array}$ & $\begin{array}{cc}36,101 & 31,746 \\
(277 ; 2,624) & (315 ; 997)\end{array}$ & $\begin{array}{c}25,062 \\
(399 ; 1,408)\end{array}$ \\
\hline$\left[\mathrm{Cu}(\text { hmyp }) \mathrm{Cl}_{2}\right]_{2}(\mathbf{4})$ & $\begin{array}{l}\text { Overlapp } \\
\text { Overlapp }\end{array}$ & $\begin{array}{l}\text { ed bands below } 500 \mathrm{~nm} \\
\text { ed bands below } 500 \mathrm{~nm}\end{array}$ & $\begin{array}{c}15,974 \\
(632 ; 145)^{\mathrm{a}} \\
14,204 \\
(704 ; 150)^{\dagger, \mathrm{a}}\end{array}$ \\
\hline
\end{tabular}

${ }^{\dagger}$ DMSO - dimethyl sulfoxide; ${ }^{\ddagger}\left\{\right.$ wavelength; extinction coefficient $\left.\left(\mathrm{L} \mathrm{mol}^{-1} \mathrm{~cm}^{-1}\right)\right\} ;{ }^{\#}$ estimated lowest energy band due to saturation of the detector; ${ }^{\mathrm{a}} d-d$ lowest energy transition. 


\subsection{Antimicrobial activity}

The potential of these copper(II) complexes to become antimicrobial drugs was tested for activity against Staphylococcus aureus (ATCC 33591) and Bacillus subtillis (ATCC 23858) (Gram-positive), and Escherichia coli (ATCC 29214) and Salmonella typhimurium (ATCC 14028) (Gram-negative) microorganisms. The 3-hmp was inactive against all of these microorganisms. The 4-hmp was only active against S. aureus and B. subtillis similarly to Amoxicillin as showed in Table 2. Considering that both compounds, 4-hmp and Amoxicillin, have a hydroxyl group at the para position of the phenyl ring, Fig. 1 and 4, this group is hypothetically a good candidate for being the chemical site in the biochemical interaction with the Grampositive microorganisms.<smiles>CC1(C)S[C@@H](NC(=O)[C@@H](N)c2ccc(O)cc2)C(=O)N1C(=O)O</smiles>

Amoxicillin<smiles>CCn1cc(C(=O)O)c(=O)c2cc(F)c(N3CCNCC3)cc21</smiles>

Norfloxacin

Figure 4. Structure of the commercial drugs

The hmyp was active as Norfloxacin against E. coli, but the former compound was practically 1000 times less active in comparison to this commercial drug, giving activity against this microorganism only. Since these compounds have no common structural moieties, it becomes difficult to envisage a possible structural correlation between them for the biochemical interaction with the $E$. coli.

Upon coordination, the free para and ortho hydroxyl groups from 3- and 4-hmp did not have any influence on the antimicrobial activity because its copper(II) derivatives, complex-1, 2 and $\mathbf{3}$, were inactive against the Gram-negative and Gram-positive microorganisms. Nevertheless, copper(II) chloride was active against $S$. aureus and B. subtillis, which led to postulate that the coordination of 3- and 4-hmp to the metal ion deactivate the copper(II) derivatives towards the antimicrobial activity. The absence of a synergistic effect between the copper(II) ion and both 3- and 4-hmp is most likely one of the reasons for these complexes not being active against the microorganisms tested. Complex-4 was only active against $S$. aureus and B. subtillis.. For this complex, a synergistic effect between the metal ion and the ligand appears to be crucial for the antimicrobial activity but against $E$. coli and S. typhimurium, complex-4 was inactive and copper(II) chloride as well. In this situation, the synergistic effect in complex-4 was not significant to the antimicrobial activity owing probably to an "intrinsic resistance" in connection to the extra membrane cell wall of the Gram-negative bacteria [9].

Table 2. Antimicrobial data* of the copper(II)-Schiff base complexes.

\begin{tabular}{lllll}
\hline Compound & S. aureus & B. subtillis & E. coli & S. typhimurium \\
\hline & & & & \\
4-hmp & $195(42)$ & $391(83)$ & $n a$ & $n a$ \\
hmyp & $n a$ & $n a$ & $1726(333)$ & $n a$ \\
{$\left[\mathrm{Cu}(\text { hmyp }) \mathrm{Cl}_{2}\right]_{2}(4)$} & $508(165)$ & $1017(332)$ & $n a$ & $n a$ \\
Amoxicillin & 14.2 & 0.4 & $n a$ & $n a$ \\
Norfloxacin & 16.2 & 4.1 & 1.8 & 16.2 \\
$\mathrm{CuCl}_{2} \cdot 2 \mathrm{H}_{2} \mathrm{O}$ & 1951 & 1951 & $n a$ & $n a$ \\
& & & &
\end{tabular}

*MIC - $\mu \mathrm{M}\left(\mu \mathrm{g} \mathrm{mL}{ }^{-1}\right) ; n a-$ not active

The geometrical arrangements of coordination compounds may also be important to antimicrobial activity. For instance, octahedral copper(II) derivatives of 1,2,4-triazole Schiff bases showed considerable antibacterial activity in comparison to the corresponding free ligands. The MIC of these octahedral copper(II) compounds was in the range of 25 to $100 \mu \mathrm{g} \mathrm{mL} \mathrm{m}^{-1}$ against $S$. aureus and E. coli [12]. Monomeric and dimeric square pyramidal in addition to square planar copper(II) derivatives of substituted imidazole showed $\mathrm{IC}_{50}$ in the region of $43 \mu \mathrm{M}$ on U937 Leukemia cell line but these compounds did not show any chemotherapeutic potential on other Leukemia and Melanoma cell lines [22]. Square pyramidal copper(II) derivatives of 2,6diacetylpyridine bis(benzenesulfonohydrazide) Schiff base also showed antimicrobial activity against $S$. aureus (MRSA 0701-4, MRSA 1, MRSA 0307-28, MRSA 0302-4, MRSA 0704-3). Although the free 2,6- 
diacetylpyridine- Schiff base were not active, the MIC of the corresponding square pyramidal copper(II) derivatives were in the range of 1250 to $5000 \mu \mathrm{g} \mathrm{mL} \mathrm{m}^{-1}$ [16]. The bioassay datum of complex-4 revealed MIC values at $165 \mu \mathrm{g} \mathrm{mL}^{-1}$ against $S$. aureus (ATCC 33591) and $332 \mu \mathrm{g} \mathrm{mL}^{-1}$ for B. subtillis, which is equivalent to the free hmyp ligand for E. coli. The MIC of the 4-hmp ligand was below $100 \mu \mathrm{g} \mathrm{m}^{-1}$ for S. aureus (ATCC 33591) and B. subtillis (ATCC 23858), showing a better result in comparison to complex-4. Nevertheless, this complex reveal MIC values of antimicrobial activity comparable to other copper(II) Schiff base derivatives.

The electronic properties of the copper(II)-Schiff base compounds in this work may also give an insight into the bioassay results. The electronic spectra of complex-1, $\mathbf{2}$ and $\mathbf{3}$ (see Table 1) showed MLCT bands which are regarded as an internal redox process in compounds presenting such electronic properties [21]. Consequently, it is conceivable that this chemical property might be a contributing factor to the polarization of these compounds to get across the cell wall of the microorganisms. A common chemical aspect between copper(II)-1,2,4-triazole- or copper(II)-2,6-diacetylpyridine- Schiff base derivatives and complex-4 is that all of them exhibited $d$ - $d$ electronic transitions. This chemical property reinforces that an internal redox process in complex-1, 2 and 3, by the MLCT bands, in addition to the lack of a synergistic effect is hypothetically the source of these copper(II) compounds not being effective against the Gram-positive and Gram-negative microorganisms.

\section{Conclusion}

Although the mechanism of action is still unknown, a synergistic effect in complex-4 was significant to achieve antimicrobial activity against the microorganisms tested. It is assumed that upon coordination of 3-and 4-hmp, the biochemical interaction of the corresponding copper(II) derivatives with the microorganisms is deactivated by an internal redox process. Based on the MIC values of complex-4, 4-hmp and hmyp ligands, these compounds might eventually be useful as part of the chemical composition of medicines for human illnesses treatment.

\section{Acknowledgments}

The authors are grateful to FAPEMIG, CAPES and CNPq for financial support.

\section{References}

[1]. B.S. Creaven, B. Duff, D.A. Egan, K. Kavanagh, G. Rosair, V.R. Thangella, M. Walsh, Anticancer and antifungal activity of copper(II) complexes of quinolin-2(1H)-one-derived Schiff bases, Inorganica Chimica Acta, 363, 2010, 4048-4058.

[2]. A.N. Kursunlu, E. Guler, F. Sevgi, B. Ozkalp, Synthesis, spectroscopic characterization and antimicrobial studies of Co(II), Ni(II), $\mathrm{Cu}(\mathrm{II})$ and $\mathrm{Zn}$ (II) complexes with Schiff bases derived from 5-bromo-salicylaldehyde, Journal of Molecular Structure, 1048, 2013, 476-481.

[3]. B.K. Singh, A. Prakash, H.K. Rajour, N. Bhojak, D. Adhikari, Spectroscopic characterization and biological activity of Zn(II), $\mathrm{Cd}(\mathrm{II}), \mathrm{Sn}$ (II) and $\mathrm{Pb}$ (II) complexes with Schiff base derived from pyrrole-2-carboxaldehyde and 2-amino phenol, Spectrochimica Acta Part A: Molecular and Biomolecular Spectroscopy, 76, 2010, 376-383.

[4]. X. Qiao, Z.-Y. Ma, C.-Z. Xie, F. Xue, Y.-W. Zhang, J.-Y. Xu, Z.-Y. Qiang, J.-S. Lou, G.-J. Chen, S.-P. Yan, Study on potential antitumor mechanism of a novel Schiff Base copper(II) complex: Synthesis, crystal structure, DNA binding, cytotoxicity and apoptosis induction activity, Journal of Inorganic Biochemistry, 105, 2011, 728-737.

[5]. G.B. Bagihalli, P.S. Badami, S.A. Patil, Synthesis, spectral characterization and in vitro biological studies of Co(II), Ni(II) and $\mathrm{Cu}$ (II) complexes with 1,2,4-triazole Schiff bases, Journal of Enzyme Inhibition and Medicinal Chemistry, 24, 2009, $381-394$.

[6]. F. Arjmand, F. Sayeed, M. Muddassir, Synthesis of new chiral heterocyclic Schiff base modulated Cu(II)/Zn(II) complexes: Their comparative binding studies with CT-DNA, mononucleotides and cleavage activity, Journal of Photochemistry and Photobiology B: Biology, 103, 2011, 166-179.

[7]. K. Dhahagani, S. Mathan Kumar, G. Chakkaravarthi, K. Anitha, J. Rajesh, A. Ramu, G. Rajagopal, Synthesis and spectral characterization of Schiff base complexes of $\mathrm{Cu}$ (II), $\mathrm{Co}$ (II), Zn(II) and VO(IV) containing 4-(4-aminophenyl)morpholine derivatives: Antimicrobial evaluation and anticancer studies, Spectrochimica Acta Part A: Molecular and Biomolecular Spectroscopy, 117, 2014, 87-94.

[8]. S.A. Zacchino, M.P. Gupta, Manual de Técnicas in vitro para la Deteccíon de Compuestos Antifúngicos (Corpus Editorial Y Distribuidora, Rosario: 2007).

[9]. S.M. Abdallah, G.G. Mohamed, M.A. Zayed, M.S.A. El-Ela, Spectroscopic study of molecular structures of novel Schiff base derived from o-phthaldehyde and 2-aminophenol and its coordination compounds together with their biological activity, Spectrochimica Acta Part A: Molecular and Biomolecular Spectroscopy, 73, 2009, 833-840.

[10]. L.H. Abdel-Rahman, R.M. El-Khatib, L.A.E. Nassr, A.M. Abu-Dief, F.E.-D. Lashin, Design, characterization, teratogenicity testing, antibacterial, antifungal and DNA interaction of few high spin Fe(II) Schiff base amino acid complexes, Spectrochimica Acta Part A: Molecular and Biomolecular Spectroscopy, 111, 2013, 266-276.

[11]. R.M. Silverstain, G.C. Bassler, T.C. Morril, Spectrometric Identification of Organic Compounds (John Wiley \& Sons Inc, New York: 1991).

[12]. G.B. Bagihalli, P.G. Avaji, S.A. Patil, P.S. Badami, Synthesis, spectral characterization, in vitro antibacterial, antifungal and cytotoxic activities of $\mathrm{Co}(\mathrm{II}), \mathrm{Ni}(\mathrm{II})$ and $\mathrm{Cu}(\mathrm{II})$ complexes with 1,2,4-triazole Schiff bases, European Journal of Medicinal Chemistry, 43, 2008, 2639-2649.

[13]. K. Nakamoto, Infrared and Raman Spectra of Inorganic and Coordination Compounds Part B: Applications in Coordination, Organometallic, and Bioinorganic Chemistry (John Wiley \& Sons Inc, NY: 1997). 
[14]. Y. Jiang, J. Xue, X. Wen, Y. Zhai, L. Yang, Y. Xu, G. Zhao, K. Kou, K. Liu, J.e. Chen, J. Wu, Sugar-metal ion interactions: The coordination behavior of cesium ion with lactose, d-arabinose and 1-arabinose, Journal of Molecular Structure, 1109, 2016, 179191.

[15]. S. Chandra, A.K. Sharma, Nickel(II) and copper(II) complexes with Schiff base ligand 2,6-diacetylpyridine bis(carbohydrazone): Synthesis and IR, mass, 1H NMR, electronic and EPR spectral studies, Spectrochimica Acta Part A: Molecular and Biomolecular Spectroscopy, 72, 2009, 851-857.

[16]. J. Yusnita, S. Puvaneswary, H. Mohd. Ali, W.T. Robinson, T. Kwai-Lin, Synthesis, structural characterization and antibacterial activity of 2,6-diacetylpyridine bis(benzenesulfonohydrazide) Schiff bases and their copper(II) complexes, Polyhedron, 28, 2009, 3050-3054.

[17]. M. Mishra, K. Tiwari, P. Mourya, M.M. Singh, V.P. Singh, Synthesis, characterization and corrosion inhibition property of nickel(II) and copper(II) complexes with some acylhydrazine Schiff bases, Polyhedron, 89, 2015, 29-38.

[18]. W. Linert, P. Weinberger, G. Ondrejovic, D. Makanova, Vibrational spectroscopy to analyze peripheral isomerism in tetranuclear mixed halide copper(II)-complexes, Vibrational Spectroscopy, 5, 1993, 101-108.

[19]. S. Sakaguchi, K.S. Yoo, J. O'Neill, J.H. Lee, T. Stewart, K.W. Jung, Chiral Palladium(II) Complexes Possessing a Tridentate NHeterocyclic Carbene Amidate Alkoxide Ligand: Access to Oxygen-Bridging Dimer Structures, Angewandte Chemie International Edition, 47, 2008, 9326-9329.

[20]. H.L. Shyu, H.H. Wei, G.H. Lee, Y. Wang, Synthesis and Characterisation of a New Binuclear Copper(II) Complex with an Oxygen Bridge and a B-N Bonded Ligand, Inorganic Chemistry, 35, 1996, 5396-5398.

[21]. J.E. Hueeye, E.A. Keiter, R.L. Keiter, Inorganic Chemistry Principles of Structure and Reactivity (HarperCollins College Publishers, NY: 1993).

[22]. S. Godlewska, J. Jezierska, K. Baranowska, E. Augustin, A. Dołęga, Copper(II) complexes with substituted imidazole and chlorido ligands: X-ray, UV-Vis, magnetic and EPR studies and chemotherapeutic potential, Polyhedron, 65, 2013, $288-297$.

[23]. O.O.E. Onawumi, O.A. Odunola, E. Suresh, P. Paul, Synthesis, structural characterization and microbial activities of mixed ligand copper(II) complexes of 2,2'-bipyridine and acetylacetonate, Inorganic Chemistry Communications, 14, $2011,1626-1631$.

[24]. A.P. Singh, N.K. Kaushik, A.K. Verma, G. Hundal, R. Gupta, Synthesis, structure and biological activity of copper(II) complexes of 4-(2-pyridylmethyl)-1,7-dimethyl-1,4,7-triazonane-2,6-dione and 4-(2-pyridylethyl)-1,7-dimethyl-1,4,7-triazonane-2,6-dione, European Journal of Medicinal Chemistry, 44, 2009, 1607-1614. 